Article type : Original Article

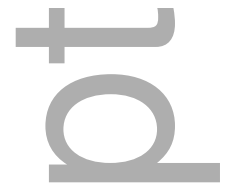

Corresponding author E-mail address : Abbey.MacDonald@utas.edu.au

\title{
Designing STEAM education: Fostering relationality through design-led disruption
}

Keywords: STEAM, inter-disciplinary curriculum, Collaborative inquiry, relational pedagogy, experiential learning

Introduction

Discussion pertaining to the relationship between STEM and STEAM education in Australia continues to draw significant coverage across scholarly inquiry, political speech and popular commentary contexts (Author 1 \& Author 2 2018). Beyond Australia, curiosity and interest around the challenges and benefits inherent to STEM and STEAM education priorities and possibilities, and implications for industry, are similarly continuing to build (Liao 2016; Maslyk 2016; Yakman \& Lee 2012).

Simultaneously, it appears that arguments against a STEAM agenda in relation to STEM are diminishing, challenging the notion that both acronyms may amount to nothing more than fleeting education buzzwords. Harris and de Bruin (2017) assert that "there is no defensible reason why the ' $A$ ' of arts should not be included in domain interconnectedness and the development of critical and creative thinking skills preparation of students for the global economy" (56). It is clear that STEM/STEAM discourses reach far beyond any measure of squabbling over which acronym might be deemed 'best' or 'right'. As such, arguments around what the acronym should or should not include are largely redundant. It is intriguing to see how a simple acronym, with contentions around what the letters represent, and how those letters might be best arranged, has revealed the emphasising or under-representation of entire disciplinary fields in education.

\section{STEM, STEAM and the space between}

This is the author manuscript accepted for publication and has undergone full peer review but has not been through the copyediting, typesetting, pagination and proofreading process, which may lead to differences between this version and the Version of Record. Please cite this article as doi: $10.1111 /$ JADE.12258

This article is protected by copyright. All rights reserved 
It can be inferred from the STEM/STEAM literature and commentary in Australia, that research and curriculum developers continue to grapple with different, disparate or conflicting interpretations of how STEM education unfolds from the theory-practice nexus. The push for and push back against a STEAM conversation in relation to STEM serves to further complicate and iterate contentions (Author 1 \& Author 2 2018). Liao (2016) offers a perspective that compels STEM/STEAM theorists and practitioners alike to divert their attention from attempts to reconcile hierarchal disciplinary competition to instead invest in the spaces between disciplines. An arts-integrated approach to STEAM education where teaching and learning concentrate on and derive from the liminal and relational spaces between disciplines can open up a transdisciplinary space-a space that is at once oriented between, across and beyond all disciplines (Liao 2016; Nicolescu 1997). The body of emerging literature around STEM/STEAM education posits that in order for such inter/transdisciplinary approaches to be achieved through art-integration. An understanding of the practice of STEM must first be established (Cunningham 2014; Liao, 2016; Radizwill, Benton \& Moellers 2015). In the absence of a universally agreed-upon definition of what STEM education embraces, English (2016) draws attention to the California Department of Education's (2014) broad perspective on STEM education:

"K-12 STEM education encompasses the processes of critical thinking, analysis, and collaboration in which students integrate the processes and concepts in real world contexts of science, technology, engineering, and mathematics, fostering the development of STEM skills and competencies for college, career, and life" (https://www.cde.ca.gov/PD/ca/sc/stemintrod.asp)

Such an approach is different from traditional STEM pedagogies and cannot be pursued without significant deviations in both curricula and conventional teaching methods. The successful integration of creative approaches into STEM, calls for teachers that can see the evidence that supports change and can learn how to teach alternative approaches (Bequette \& Bequette 2012). These commentaries implore us not to dismiss the potential of interdisciplinary approaches for teaching and learning. They propose that the creative and liberal arts can meet STEM disciplines in relational, empowered and empowering generative spaces of possibility in whole curriculum enactment. Harris and de Bruin (2017) describe an emerging 21st century creative crisis in schools, where "those educating in the arts [must] assert the position of the arts as significant subjects that are of meaning, value and currency within the globalised frames of education today" (64). The contention that accompanies a more visible and robust narrative for STEAM is the further disruption (or possibility) it then offers for both STEM and the Arts, as each seeks to establish significance in 
relation to respective disciplines, and to consolidate from there. Perhaps we will come to better understand what STEM and STEAM education can involve through the attention we pay to the unsettled and ambiguous 'in-between spaces'. The ways in which various disciplines might intersect (or otherwise) may be revealed in their relationalities free of the constraints definitions can impose.

\section{Fostering relationality between disciplines of origin}

Educators' disciplines of origin may be an important consideration when designing interdisciplinary engagements. Looking to the inhibitors and enablers that exist in the spaces between disciplines can prompt us to think about the nature of these 'home' disciplines for individual educators; their knowledge-making paradigms, and associated learning and teaching practices (Carey \& Matlay 2010). Explicit discussion in the planning phases of hard versus soft paradigms in an interdisciplinary engagement and how they may manifest in students' learning, may assist the development of assessment tasks and learning activities that are more embracing and responsive to the range of participating disciplines. Championing a reflective and relational approach to interdisciplinary teaching and learning design may also enable practitioners to better understand their own knowledge-making processes, and to appreciate that studio-based learning and teaching (Marshall 2014) can play a role in helping teachers to recognise how a particular paradigm may be quite foreign to students from 'hard-pure' and 'hard-applied' disciplines.

Better understanding of how relationality is inhibited or enabled within particular disciplinary paradigms can impact our conceptualization of interdisciplinary endeavors pertinent to STEAM education. The design of these may be driven by a 'host' discipline, or partnerships between disciplines and/or sub-disciplines (e.g. biology, art and design in the Midlands Restoration Project which will be discussed later). The abstract-concrete continuum suggests a need for mediating strategies in which educators can come together to develop interdisciplinary learning; or, provide support for educators trained in a single disciplinary field, to move beyond that field through interdisciplinary STEAM curriculum design.

\section{Making STEAM: disciplinary intersections for policy and practice}

The British Educational Research Association (BERA) research commission Reviewing the potential and challenges of developing STEAM education through creative pedagogies for $21^{\text {st }}$ Century learning (Colucci-Gray, Burnard, Davies, \& Stuart Gray 2017), has suggested that the term 'STEAM' is globally used to indicate engagement of the arts or art-practices (sometimes encompassing the liberal arts; humanities and social sciences) with STEM subjects of Science, Technology, Engineering and 
Mathematics. In March 2018, NSW Education Minister Rob Stokes questioned and further challenged the dominance of a STEM agenda in education in his Balmoral Lecture at Queenwood School (Smith 2018). In doing so, the Minister sparked media and scholarly commentary, including from Cunningham (2018), who reiterated in The Conversation, that 'An exploding creative economy shows innovation policy shouldn't focus only on STEM' (np), and that the most innovative Australian enterprises entangle STEM with business, creative, and communication skills, and that digital literacy skills are far wider than a STEM definition of technology. In February 2018, the Australian peak body that advocates for arts education in schools, develops arts education policy, promotes quality teaching and learning in the arts, and works with government agencies, teachers, schools and tertiary institutions (National Advocates for Art Education), met with advisers from all political parties and senior staff from the federal education and arts departments, where they asserted that arts skills are at least as important as literary and numeracy and should be prioritised alongside STEM (NAAE, 2018). These are just some of the examples of the commentary surrounding STEM/STEAM, and further demonstrate the integral role of the arts (creative and liberal) in cultivating communication capacities, entrepreneurial and exploratory thinking, and how these are quickly becoming essential for achieving innovation in the changing work environment.

In exploring the relational possibilities lingering between STEM/STEAM, we can start to get a sense of how confusion creates problems, and problems provide opportunity for reimagining and innovation. It is at this point that the arts and the sciences are on common ground. Ways of knowing, being and becoming in the world are usefully problematised at the STEM/STEAM disciplinary intersect. What we do in the spaces between the disciplines, and how those disciplines encounter each other are similarly challenging. How might we look to and leverage from the STEM/STEAM entanglement in context to better understand how students learn and teachers educate in truly inter- and trans-disciplinary ways? Harris's (2016) 'Creativity Index' emphasises the importance of allowing students to lead and (in turn), exercise their agency around how the dynamics of creativity can be enacted in schools. What might happen if we hand over the STEM/STEAM complication to students, as a real-world problem and site for authentic learning within their unique social, cultural and ecological contexts, for them to unravel with the support of their teachers, and to reveal to us?

\section{The Midlands Restoration Project, Tasmania, 2015 - 2018}

To explore how a STEAM education initiative unfolds in relation to the conundrums, perplexities and contentions thus far highlighted, this article looks to how a case-study STEAM education program 
evolved and was adopted in Tasmania, Australia. While Tasmania is experiencing rapid growth in its population (515,000 people as of January 2018), and has the fourth best performing economy in the country (CommSec 2018), it continues to experience significant socio-economic challenges, with the lowest level of educational attainment in Australia (Allen et al 2017). Further to this, Tasmania is reported to experience "persistent underperformance in the transition to Year 10 and subsequent retention rates to Year 12" (Stratford et al. 2016, 4). It is estimated that Tasmania is 10,000 tertiary enrolments behind the next lowest performing state, with significant challenges in encouraging students to complete Years 11 and 12 (in 2011 the retention rate for Year 12 was 78.2\%, compared with $84.1 \%$ nationally [http://www.dpac.tas.gov.au/divisions/csr]). At the same time, Tasmania is host to arguably the most vibrant interdisciplinary creative community in Australia (Grimmer 2017; Lehman \& Reiser 2014), as exemplified in a thriving local, interstate and international art exhibition calendar, and annual festivals such as the Museum of Old and New Art (MONA)'s DARK MOFO winter festival, the MONA FOMA summer festival and Junction Arts Festival (JAF).

\section{Context}

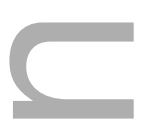

The following case study considers a sustained, four year STEAM-based curriculum project developed in the spaces between thriving creative capital, socio-economic challenge and low education attainment. The Midlands Restoration Project involved collaboration between Campbell Town District High School, the University of $x x x x x(x x x x x)$, the local Campbell Town community and surrounds, local Tasmanian Aboriginal community, and industries associated with the town of Ross, in the Northern Midlands region of Tasmania. The project explored interdisciplinary approaches to regional environmental challenges through developing public art works from their collaborative inquiry into the Midlands habitat. The art/design project interconnected with the highly successful Riparian Restoration Project of the Midlands area, co-funded by the lan Potter Foundation and Greening Australia.

As one of the most threatened landscapes in Tasmania, the Midlands region is recognised as a 'biodiversity hotspot' (Akhta-Khavari \& Richardson 2017; Richardson, 2017). In the 200 year period post-European invasion and subsequent colonisation of Australia, and the state of lutruwita/Tasmania, the original Tasmanian Midlands native vegetation has changed dramatically, with more than $80 \%$ transformed to agricultural pasture. This has resulted in the loss of vegetated habitat for local species and the fragmentation of the little that remains. The fragmented vegetated landscape in the Midlands poses a barrier to faunal movement, and restoration of habitat corridors to facilitate movement from east to west is urgently needed. One thousand hectares along rivers are 
among remnants currently undergoing revegetation to re-establish connectivity and habitat value for a range of species, creating habitats for native animals and providing multiple connections between the Western and Eastern Tiers.

\section{Process}

Following initial discussions and site-visits in 2014, the initial concept was proposed by Dr Peter Davies and Lynn Davies. The interdisciplinary team that drove the project included Author 4 and $\mathrm{Dr}$ Michael Hornblow from the University of xxxxx's School of Architecture and Design; as well as the artists Lucy Bleach, Patrick Sutczak, John Vella and Author 2 from the School of Creative Arts. These creative practitioners worked in collaboration with Greening Australia, the University of xxxxx's School of Land and Food and the ARC Centre for Forest Value at the University of xxxxx. The site for the public art works was donated by Midlands farmer, Julian von Bibra.

A series of four 'Species Hotels'was created with the support of seed funding from the University of xxxxx. They were designed and built by 60 first year Architecture and Interior Design as a live studio project, however the design process was far more encompassing, participatory and inclusive than usually permitted. It involved multi-stakeholder collaboration for interdisciplinary learning where local school children (22 year 2/3 students \& 8 year 9 art students), environmental scientists (7), artists (4), designers (4), school teachers (3) and Greening Australia (2) worked together in the design process. The 'design workshop' was held in the local Town Hall, and just a short walk to the Macquarie river site where evidence of significant tree planting could be observed. Both tertiary and primary level students responded to the project brief through site sensing and model making. This model, of an inter-disciplinary 'design workshop' in collaboration with school students, became a defining feature of the project and repeated for subsequent projects each year.

Based on initial studies, the lan Potter Foundation provided further funding which allowed the designs to be developed into a more ambitious series of public artworks, over an extended timeline. As a result, two bodies of work were produced: 'Species Hotels', public artworks and seating installed at a public site at Ross, led by Author 4 and Author 2; and, 'Nightlight: Species Hotel - a Game Lab' led by Dr Michael Hornblow, a suite of design propositions that manifested as a gamedriven installation, initially staged as part of the Junction Arts Festival (JAF) in Launceston, Northern Tasmania. Further works have continued to be developed by Author 4 (Bird Hide and Native Bee Hotels) and Hornblow (Ruins) with their students accessing the networks established with the first project.

This article is protected by copyright. All rights reserved 


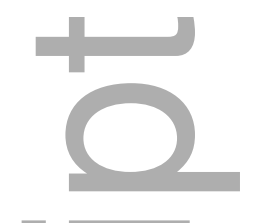

Figures 3, 4, 5: Species Hotels inserted here (Images by Nina Hamilton) $\infty$

\section{Disrupted disciplines: Discussion for design}

Design is a multivalent concept across different disciplines which reflects "action aimed at changing existing situations to preferred ones" (Simon 1996, 108). To design demands the mediation of arts and sciences to 'satisfice' a need, although the mix and integration of the arts and sciences depends on how the problem/solution is framed and reflects the discipline or community of practice (Boubasci 2008, Lawson 1997, Wenger 1998). Due to this variety, design can be considered a troublesome concept to teach, ultimately relying on experiential learning. Opportunities for experiential learning are especially important in enabling students to explore, in context, possibilities for multiple correct solutions. Such opportunities help ensure goals are meaningful and authentic and representations or evidence of learning can ensue (Moon 2004). These contextual characteristics and approaches can be embracing of ill-structured material, lending themselves to disrupting disciplines as a means for reconciling competing demands.

The 'live' design/build projects in Architectural Education (Morrow 2014, Salama 2015) are a useful tool and process to allow different disciplines knowledges to come together in meaningful ways. In many instances, they have been found to be transformational experiences (Meyer \& Land 2006), as the process challenges students' perception of what is involved, or what is a good solution through play, testing and discussion. The process of design involves students working in small teams to collaboratively design through a series of physical models at different scales, to ensure multiple authorship and allow greater clarity for all to read and comment. Research has shown that many students experience a fundamental shift in their understanding "when an idea is translated into 
reality" through design and fabricating a public work for the community (Another \& Author 4 2017: 76).

The 'Species Hotel' brief required students to communicate, inspire and highlight the plight of endangered species in the Midlands and the need for habitat. It equally needed to provide suitable habitats for specific species until the 300,000 seedlings sufficiently grew in order to safely weather and degrade in event of flooding along the river. These works provide a proof of concept of what may be possible if a larger Sculpture walk were to be instigated through the means of increased budget and fostering partnerships. The 'Species Hotels' were hosted by Architecture as a design studio project, however there were significant partnerships made across the University of xxxx Fine Arts and Sciences faculties, as well as Greening Australia to conceive, teach and critique the work. It required significant trust and preparation even before students commenced. The cost and time of collaboration cannot be overlooked (Jagodzinski, 2015), nor extended to a Consulting Engineer or Technical Staff, as processes associated with installation and permit from the local Council require patience and persistence. Such a diverse team was required to ensure different needs were met and to disrupt disciplines biases.

The student group were relatively homogenous in their design discipline, but diverse in their backgrounds (local and interstate school leavers, mature age students and South-East Asian students). The inclusion of the school students in the 'Species Hotel' project was a way to foster community engagement and communication. It was deliberate choice to involve young children in the design process as they were unencumbered in asking questions of our science experts. Many times, their innocent or sophisticated questions helped to dispel common assumptions or misunderstandings of animals' needs. In addition, the participation of school children meant that scientists were challenged to present information in a concise and engaging manner that also catered for tertiary students. The connection with Campbell Town District High School was enabled through the work of Greening Australia with the School.

The studio methodology was based on immersing the students in three different disciplinary fields: architecture, art and science. Academics and industry professionals each contributed to the design brief development and subsequent responses. Scientists from the University of xxxxx School of Land and Food, and the ARC Centre for Forest Value presented short interactive talks on the lifecycle and environmental challenges faced by different native species (across five broad categories: insects, marsupials, carnivores and two sizes of bird); feedback focused on viability as habitat. The night before the design workshop, a number of these scientists took participants spotlighting on a nearby 
farm to learn about micro-bats. Artists from the University of xxxxx School of Creative Arts participated in studio critique sessions, where initial designs were presented for formal critique; their comments focussing on audience engagement with the constructions as public artworks. Architects and designers focused on facilitating students' learning experience in understanding the different role of 'client', discipline expectations, languages to support a successful outcome. Students also had access to a consulting Engineer and technical staff during the process.

Overall, the 'design-build' of four full-scale constructions took six weeks. At the initial proposed time of installation, the site had become impassable due to flooding, so the works were installed into the Inveresk Gallery for the summer period. It was fortuitous as it created a larger news story and drew a larger audience to the objectives of the 'Species Hotels', as well as easier access for many local school groups. Students from Campbell Town District High School also visited and undertook their own design-build projects in Architecture and Design workshops. Due to the success of this smaller design/build activity for school children, it has subsequently been developed and used with a number of local schools. Senior students have developed it further to form part of educational resource used by the Timber Products association.

The Species Hotels were eventually installed and launched in their intended Midlands site in September 2017 as part of 'International Biodiversity Day', with 65 first-year Architecture and Interior design students involved in an on-site workshop, as well as 27 students from Campbell Town District High School. This again included 'field' presentations by scientists, artists and architects, speaking to the design processes engaged in the construction, as well as their disciplinary perspectives on the final outcomes.

The final component of the 'Species Hotels' was completed in June 2018, with the installation of seating designed by a local craftsperson in collaboration with the artist Author 2 and the opening of the public footpath. Forty school children and twenty architecture students met with scientists and conservationists on site to review drawings and models for further species habitat restoration projects, as well as insect, animal and bird spotting. Students were welcomed by land owner Julian von Bibra, a XXXXX PhD zoology candidate, a Tasmanian Aboriginal community representative and Greening Australia's Sebastian Burgess who gave an overview of the Tasmanian Island Ark project, that is restoring habitat for native species in the Midlands. Storied excerpts from participant stakeholders involved in the STEAM collaboration are offered here (centred and in italics), providing insight into the relational outcomes generated in process and from products deriving from this STEAM education collaborative venture: 
Local birds of prey expert Nick Mooney got everyone excited with his taxidermized birds and noted the students had good young eyes for bird spotting. Exploring the Species Hotels beside tinamirakuna /the Macquarie River the students excitedly spotted four endangered wedge-tailed eagles circling overhead.

Greening Australia Education Coordinator Nel Smit said, "The students have been engaged in the Species Hotels project for three years and were excited to see the how the hotels are being used by animals. They found a big bird nest and a bee hive in one of the sculptures.

Further to the Species Hotel project, 'Nightlight: Species Hotel - a Game Lab' unfolded as a parallel body of work led by Dr Michael Hornblow, Senior Lecturer in Digital Technologies in Design and Art, Architecture and Design at xxxx. Again, using an interdisciplinary team of students and academics, the work engaged with a number of schools in the design process. Students were encouraged to invent games based on the thematics of the project, which were reviewed and some adopted in the final design responses developed by students in the disciplines of Architecture and Information Technology. The resulting work was presented publicly at the annual Junction Arts Festival in Launceston in September 2017, with iterations later re-staged in Ross to coincide with the 'Species Hotels' launch events:

Species Hotel is an open game lab exploring biodiversity and habitat restoration, a transmedia ecology of many 'species' - plant, animal, human, technology. Based in the shopfront of the Wilderness Society for Junction's Night Light program, the lab seeks to raise awareness around Greening Australia's Restoration Corridor along the Macquarie river in the Tasmanian Midlands. This larger project supports a biodiversity hotspot where over 300,000 native plants have been established to enhance animal habitat.

The Lab provided a transmedia experience of participatory art and design, incorporating digital interfaces and physical objects, from traditional game platforms to virtual and augmented reality, social media, 3D printing, sculpture, video and performance. Audiences explored a gamified ecology where the interaction of animal species and landscape elements created a series of 'flow-on' effects. These became layered over time to produce an evolving narrative of virtual territories, physical artefacts and embodied movement (Nightlight: Species Hotel - a Game Lab (2017). Retrieved from: https://junctionartsfestival.com.au/archive/2017/species-hotel-a-game-lab)

Design-led disruption from the spaces between STEAM

This article is protected by copyright. All rights reserved 
A significant feature of the Midlands Restoration Project is the use of 'design' practices as a means to link learners, disciplines and stakeholders. The multiple disciplinary perspectives presented by a diverse range of experts through the design workshops provided a framework in which the arts and the sciences (here, visual art, architecture, information technology and environmental science) were able to engage with students horizontally and collaboratively, rather than in a hierarchical model. This could be described as a 'pluridisciplinary' rather than 'multidisciplinary' approach (Davies \& Devlin 2010). Significantly, design plays a role in allowing both learners and educators to re-define disciplinary structures to new ends. The recognition of design as disruptor to discipline, and discipline in and of itself, has been debated as to its distinctive knowledge, methods and processes (e.g. Cross's (2006) 'designerly ways of knowing'), while also being characterised as an interface discipline, largely devoid of its own subject matter (Jonas 2004). The distinctive ways of working demonstrated by the postgraduate business, engineering and design students in Bailey's experience (2010), lends weight to the existence of both 'designerly ways', and the enculturation of students to preferred discipline-specific approaches to learning. The Midlands Restoration Project, and the many tangent inquiry processes and products that it birthed, arguably demonstrates one such example of a design function as an 'interface discipline', contributing to detangle the STEM/STEAM complication with students, focusing on a real-world problems as the site for authentic learning.

It seems that while discipline fields within STEM and arts might bicker at each other from the sidelines around their various definitions, or balancing hierarchy of priorities to be established, something organic is taking shape at the coal face that we risk overlooking (Author 1 \& Author 2 2018). There is nothing to lose and much to be gained from educational researchers across the STEM and arts disciplines yielding to the contested space between disciplines as a relational site, where working together and in close collaboration with teachers and policy makers is essential to enabling local experiments that challenge, enhance and expand the possibilities of curricula to optimise development of $21^{\text {st }}$ Century skills. It is from here that the critical insights that will enable us to ascertain the "possibility of a more dialogic and dynamic engagement with and in STEAM practice" (Colucci-Gray et al.,, 2017, p. 73), can unfold. 'Designerly' teaching and learning practices may provide an interface between disciplines, allowing new forms of STEAM education to take place, as suggested by the Midlands Restoration Project case study.

There are many directions the conversations around STEM and STEAM might take from here. Some may seek to erode STEAM as a simplistic bid for the arts to somehow make STEM subjects more engaging, while others might advocate for the arts as the mechanism through which to challenge and resolve ethics and values underpinning inquiry in science and technology. The STEM/STEAM 
conundrum, undefined and open to possibility, creates a platform for relational education and inquiry that is all at once curious, provocative, disruptive and complex. This complexity in itself reflects the very essence of powerful transformative teaching and learning experiences, and in turn, meaningful research. The STEM/STEAM disciplinary intersect is precisely the risky, messy, disrupted place from which $21^{\text {st }}$ century skills - in teaching and learning, industry and life - evolve.

\section{REFERENCES}

Author 1 and Author 2 (2018)

Another \& Author 4 (2017)

Akhtar-Khavari, A. \& Richardson, B. J. (2017) Ecological restoration and the law: recovering nature's past for the future, Griffith Law Review, Vol. 26, No. 2, pp. 147-153.

Allen, J. M. Wright, S. Cranston, N. Watson, J. Beswick, K. \& Hay, I. (2018) Raising levels of school student engagement and retention in rural, regional and disadvantaged areas: is it a lost cause? International Journal of Inclusive Education, Vol. 22, No. 4), pp. 409-425.

Bequette, J. W. \& Bequette, M. B. (2012) A place for art and design education in the STEM conversation. Art Education, Vol. 65, No. 2, pp. 40-47.

Bailey, M. (2010) Working at the edges. Networks, Vol. 11, pp. 42-45.

Bousbaci, R. (2008) Models of man in design thinking: The bounded relationality episode, Design Issues, Vol. 24, No. 4, pp. 38-52.

Buchanan, S, Harlan, M. A. Bruce, C. S. \& Edwards, S. L. (2016) Inquiry based learning models, information literacy, and student engagement: A literature review. School Libraries Worldwide, Vol. 22, No. 2, pp. 23-39.

California Department of Education. (2014). Science, technology, engineering, \& mathematics (STEM) information. Available at: https://www.cde.ca.gov/PD/ca/sc/stemintrod.asp

Carey, C. \& Matlay, H. (2010) Creative disciplines education: a model for assessing ideas in entrepreneurship education? Education+Training, Vol. 52, No. 9, pp. 694-709.

Colucci-Gray, L. Burnard, P. Davies, R. Stuart Gray, D. (2017) Reviewing the potential and challenges of developing STEAM education through creative pedagogies for $21^{\text {st }}$ learning: How can school curricula be broadened towards a more responsive, dynamic and inclusive form or 
education, British Association for Research in Education (BERA) research commission. Available at: https://jotrowsdale.files.wordpress.com/2017/11/bera-research-commission-reportsteam.pdf

CommSec Research (2018). What's the economic state of our states? Available at: https://www.commbank.com.au/guidance/economy/commsec-state-of-the-states-reportjanuary-2018-201801.html

Cunningham, M. (2014). "From STEM to STEAM: The potential for arts to facilitate innovation, literacy, and participative democracy." The Impact Blog, London School of Economics and Political Science. Available at:

from http://blogs.Ise.ac.uk/impactofsocialsciences/2014/03/14/stem-to-steam-creativeinnovation/

Cunningham, S., (2018). An exploding creative economy shows innovation policy shouldn't focus only on STEM, The Conversation, retrieved from: https://theconversation.com/an-explodingcreative-economy-shows-innovation-policy-shouldnt-focus-only-on-stem-93732

Cross, N. (2006) Designerly ways of knowing. London: Springer.

Davies, M, \& Devlin, M. (2010) Interdisciplinary Higher Education. In M. Davies, M. Devlin, \& M. Tight [Eds] Interdisciplinary Higher Education: Perspectives and Practicalities. Bingley: Emerald House Publishing, pp. 3-28.

English, L. D. (2016) STEM education K-12: perspectives on integration. International Journal of STEM Education, Vol. 3, No. 1, pp 3-14.

Fava, M. (2017) Drawing Analogies to Deepen Learning. International Journal of Art \& Design Education, Vol. 36, No. 3, pp. 315-324.

Grimmer, L. (2017) Re-inventing Central Launceston: Creating a vibrant and thriving regional city. ABC Radio, Tasmanian Northern Breakfast Program with Belinda King, Australian Broadcasting Corporation, Australia, 1 November, 2017.

Harris, A. (2016). Creativity and education. Springer.

Harris, A. \& de Bruin, L. (2017) STEAM Education: Fostering creativity in and beyond secondary schools. Australian Art Education, Vol. 38, No. 1, pp. 54-68.

Jagodzinski, J. (2015) The challenges of art education in designer capitalism: Collaborative practices in the (new media) arts. International Journal of Art \& Design Education, Vol. 34, No.3, pp. 282-295.

Jonas, W. (2004) A theory of what? In W. Jonas \& J. Meyer-Veden [Eds] Mind the gap! On knowing and not-knowing in design, Bremen: H.M. Hauschild, pp. 178-211.

This article is protected by copyright. All rights reserved 
Lawson, B. (1997) How designers think: The design process demystified. Oxford: Elsevier/Architectural.

Lehman, K. F. \& Reiser, D. (2014) The nexus between an art experience and creative tourism: Tasmania's Museum of Old and New Art. Mondes du Tourisme, Vol. 10, No. 2, pp. 19-32.

Liao, C. (2016) From interdisciplinary to transdisciplinary: An arts-integrated approach to STEAM education. Art Education, Vol. 69, No. 6, pp. 44-49.

Marshall, J. (2014) Transdisciplinarity and art integration: Toward a new understanding of art-based learning across the curriculum. Studies in Art Education, Vol. 55, No. 2, pp. 104-127.

Maslyk, J. (2016) STEAM makers: Fostering creativity and innovation in the elementary classroom. Corwin Press.

Meyer, J. \& Land, R. (2006) Overcoming barriers to student understanding: Threshold concepts and troublesome knowledge. Abdington \& New York: Routledge.

Moon J. (2004) A Handbook of Reflective and Experiential Learning. London: Routledge Falmer.

Morrow, R. (2014) Live project love: Building a framework for live projects, in H. Harriss \& L. Widdler [Eds] Architecture Live Projects: Pedagogy into Practice. London: Taylor and Francis, pp. xviiixxiii.

National Advocates for Arts Education (2018). Arts educators call for a visionary approach to arts education and creative work, media release, Available at:

http://ausdance.org.au/news/article/arts-educators-call-for-a-visionary-approach-to-artseducation-and-creative

Nicolescu, B. (1997) The transdisciplinary evolution of the university: Condition for sustainable development, International Center for Transdisciplinary Research. Available at: http://cirettransdisciplinarity.org/bulletin/b12c8.php

Salama, A. (2015) Spatial deign education: New directions for pedagogy in architecture and beyond. Surrey: Ashgate.

Simon, H. (1996) The sciences of the artificial (Third ed.). Cambridge: MIT Press.

Statford, E. Field, M. Grant, O. \& Ambrose, K. (2016) Summary of insights of Three Round-Figure Discussions on Educational Attainment in Tasmania incorporating the involvement of Honourable Henry De Sio Jr. Available at: http://www.utas.edu.au/ data/assets/pdf file/0009/892521/Underwood 2016RoundFig ure EdAttain.pdf

Richardson, B. J. (2017) Restoring layered geographies: ecology, society and time. Griffith Law Review, Vol. 26, No. 2, pp. 154-177.

This article is protected by copyright. All rights reserved 
Smith, A. (2018) STEM has become a buzzword and a fad: NSW education minister, The Sydney Morning Herald, 21 March, 2018. Available at: https://www.smh.com.au/politics/nsw/stemhas-become-a-buzzword-and-a-fad-nsw-education-minister-20180321-p4z5iw.html

Wegner, E. (1999) Communities of practice: Learning, making and identity. Cambridge: Cambridge University Press.

Yakman, G., \& Lee, H. (2012) Exploring the exemplary STEAM education in the US as a practical educational framework for Korea. Journal of the Korean Association for Science Education, 32(6), 1072-1086.

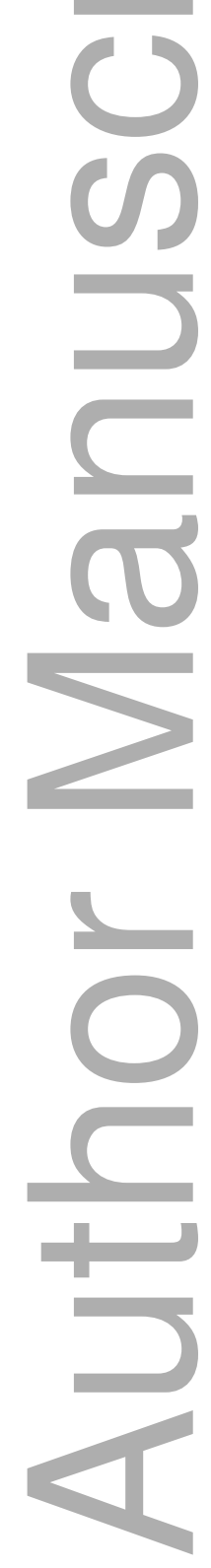



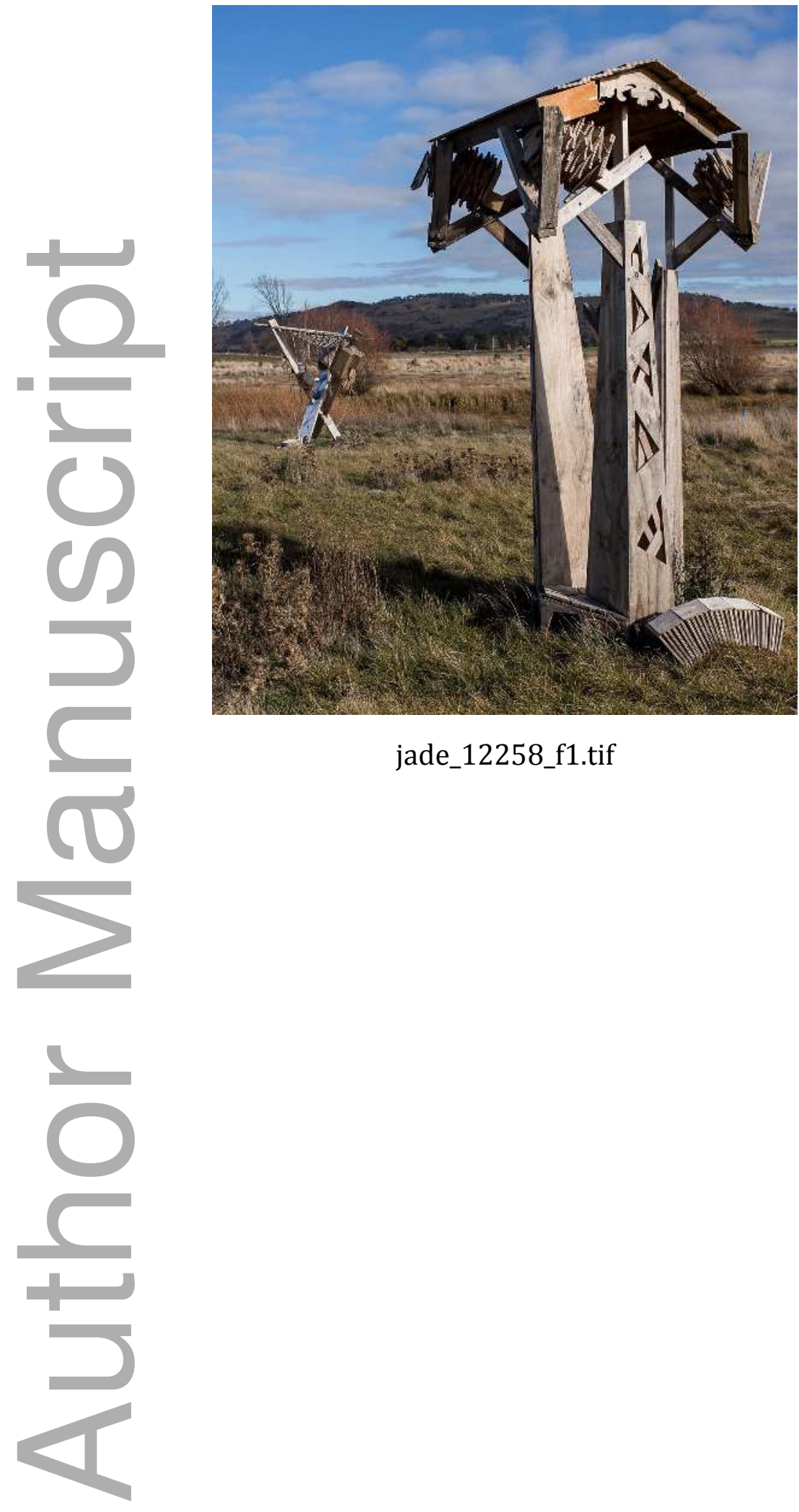

jade_12258_f1.tif 


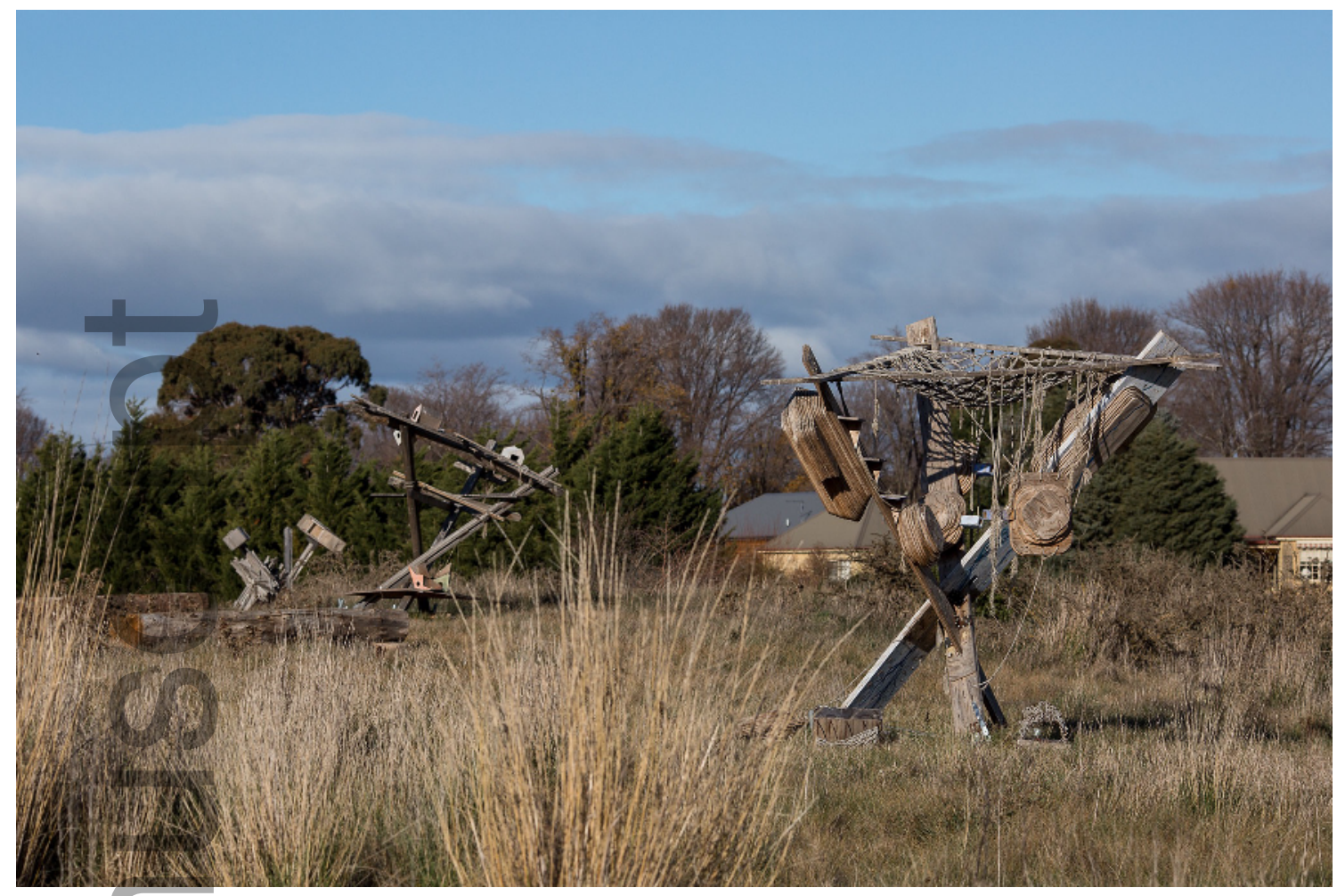

jade_12258_f2.tif

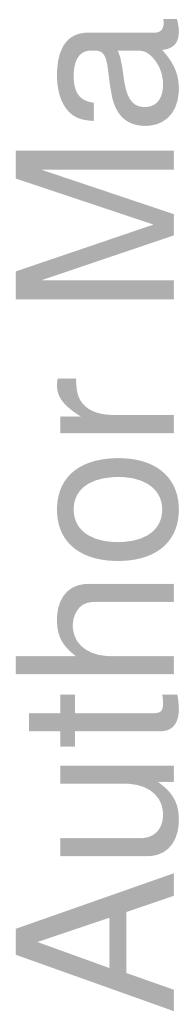

This article is protected by copyright. All rights reserved 


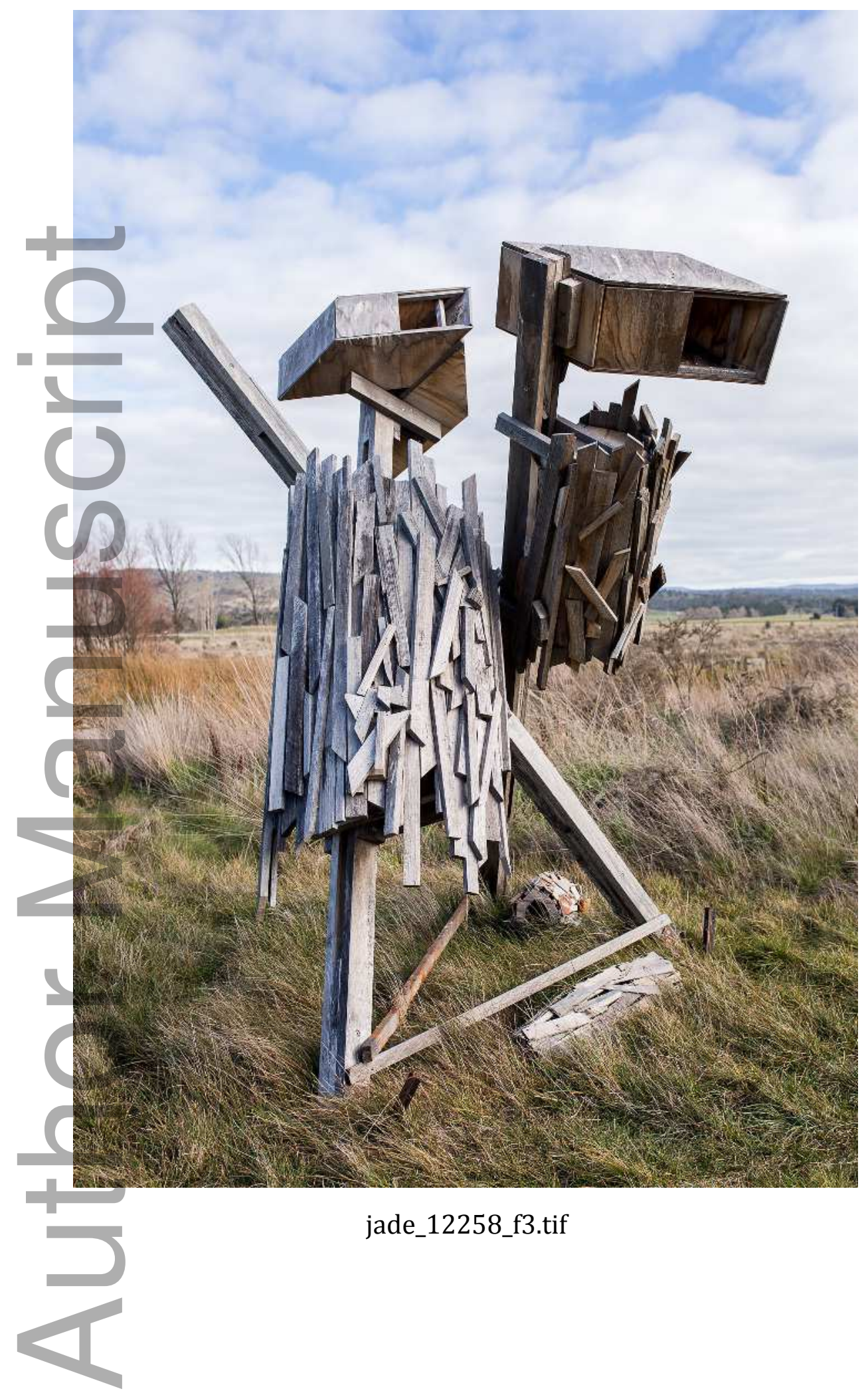

This article is protected by copyright. All rights reserved 


\section{University Library}

\section{- M M N E R VA A gateway to Melbourne's research publications}

Minerva Access is the Institutional Repository of The University of Melbourne

Author/s:

MacDonald, A;Wise, K;Tregloan, K;Fountain, W;Wallis, L;Holmstrom, N

Title:

Designing STEAM Education: Fostering Relationality through Design-Led Disruption

Date:

2019-11-11

Citation:

MacDonald, A., Wise, K., Tregloan, K., Fountain, W., Wallis, L. \& Holmstrom, N. (2019).

Designing STEAM Education: Fostering Relationality through Design-Led Disruption.

INTERNATIONAL JOURNAL OF ART \& DESIGN EDUCATION, 39 (1), pp.227-241. https:// doi.org/10.1111/jade.12258.

Persistent Link:

http://hdl.handle.net/11343/286931 